\title{
PENGARUH BUDAYA ORGANISASI DAN KEPEMIMPINAN TERHADAP KEPUASAN KERJA DAN DAMPAKNYA TERHADAP KINERJA PENGHULU
}

\author{
Nono Carsono \\ KUA Kecamatan Wanareja Kabupaten Cilacap \\ email.nono.csf@gmail.com
}

\begin{abstract}
The achievement of KUA performance in Cilacap Regency has not met expectations. These conditions can be improved and it is necessary to evaluate and research the quality of human resources so that future policies can improve employee performance and minimize factors that can reduce employee performance. The purpose of this study was to determine the effect of organizational culture and leadership on job satisfaction and its impact on the performance of the penghulu. The method used is path analysis, which is to get an overview, pattern of relationship and influence of the research variables that have been determined. The results showed that organizational culture had a positive effect on the satisfaction of the penghulu by $73.4 \%$. Leadership has a positive effect on the satisfaction of the penghulu by $73.4 \%$. Organizational culture and leadership have a positive effect on the satisfaction of the penghulu by $75.7 \%$. Organizational culture and leadership through a positive effect on the performance of the penghulu through the satisfaction of the penghulu by $85.2 \%$.
\end{abstract}

Keywords: Penghulu, Culture, Leadership, Satisfaction, Performance

\section{PENDAHULUAN}

Pemberian

kewenangan

pemerintahan yang luas kepada daerah membawa konsekuensi langsung berkurangnya kewenangan pemerintah pusat terhadap daerah dan penambahan tanggung jawab kepada daerah. Terjadinya penambahan wewenang membawa konsekuensi penambahan tugas kepada daerah. Untuk melaksanakan semua tugas itu kemudian dilakukan restrukturisasi kelembagaan. Sejalan dengan restrukturisasi yang dilakukan, dibutuhkan peningkatan kinerja pegawai agar dapat melaksanakan tugas sebaik mungkin. Untuk itu perlu diperhatikan sikap dasar pegawai terhadap diri sendiri, kompetensi, pekerjaan saat ini serta gambaran mereka mengenai peluang yang bisa diraih dalam struktur organisasi yang baru. Namun tidak dapat dipungkiri juga bahwa perubahan struktur organisasi yang baru dapat mengganggu kinerja pegawai.

Kepuasan kerja merupakan salah satu faktor yang sangat penting untuk mendapatkan kinerja yang optimal. Ketika seorang merasakan kepuasan dalam bekerja tentunya ia akan berupaya semaksimal mungkin dengan segenap kemampuan yang dimilikinya untuk menyelesaikan tugas pekerjaannya. Dengan demikian kinerja pegawai akan meningkat secara optimal. Untuk mencapai tingkat kepuasan kerja yang maksimal dalam setiap pelaksanaan akan selalu menghadapi faktor-faktor yang diperkirakan dapat mempengaruhi kepuasan kerja.

Individu yang bekerja pada suatu lingkungan atau institusi akan dipengaruhi 
oleh lingkungan tempatnya bekerja. Lingkungan tempatnya bekerja berupa budaya organisasi tempat bekerja yang akan berbeda-beda satu tempat dengan yang lain Individu harus menyesuikan perbuatannya dengan budaya organisasi tempatnya bekerja sebagai sebuah konsekuensi logis. Budaya organisasi dapat mempengaruhi kinerja individu didalamnya dan mempengaruhi kepuasan kerja individu. Budaya organisasi merupakan sistem penyebaran kepercayaan dan nilai-nilai yang berkembang dalam suatu organisasi dan mengarahkan perilaku anggotaanggotanya. Budaya organisasi dapat menjadi instrument keunggulan kompetitif yang utama, yaitu bila budaya organisasi mendukung strategi organisasi, dan bila budaya organisasi dapat menjawab atau mengatasi tantangan lingkungan dengan cepat dan tepat.

Perubahan lingkungan organisasi yang semakin kompleks dan kompetitif, menuntut setiap organisasi untuk bersikap lebih responsif agar memperthankan budaya organisasi yang baik. Proses menyelaraskan perubahan organisasi dengan perubahan individu ini tidaklah mudah. Pemimpin sebagai panutan dalam organisasi, sehingga perubahan harus dimulai dari tingkat yang paling atas yaitu pemimpin itu sendiri. Maka dari itu, organisasi memerlukan pemimpin reformis yang mampu menjadi motor penggerak yang mendorong perubahan organisasi. Sampai saat ini, kepemimpinan masih menjadi topik yang menarik untuk dikaji dan diteliti, karena paling sering diamati namun merupakan fenomena yang sedikit dipahami. Fenomena kepemimpinan di Indonesia menjadi sebuah masalah menarik dan berpengaruh besar dalam kehidupan politik dan bernegara. Dalam dunia bisnis, kepemimpinan berpengaruh kuat terhadap jalannya organisasi dan kelangsungan hidup organisasi. Peran kepemimpinan sangat strategis dan penting dalam sebuah organisasi sebagai salah satu penentu keberhasilan dalam pencapaian misi, visi dan tujuan suatu organisasi.

Maka dari itu, tantangan dalam mengembangkan strategi organisasi yang jelas terutama terletak pada organisasi di satu sisi dan tergantung pada kepemimpinan yang ada pada organisasi tersebut. Begitu pentingnya peran kepemimpinan dalam sebuah organisasi menjadi fokus yang menarik perhatian para peneliti bidang perilaku keorganisasian. Kartono (2003;12) menyatakan bahwa "kepemimpinan merupakan inti dari organisasi dan manajemen". Keberhasilan organisasi dalam mencapai tujuan yang ingin diraih bergantung pada kepemimpinannya yaitu apakah kepemimpinan tersebut mampu menggerakkan semua sumber daya yang ada secara efektif dan efisien serta terpadu dalam mencapai tujuan organisasi. Seiring dengan perkembangan teknologi informasi yang semakin cepat dan perekonomian Indonesia yang kurang stabil, hal ini bisa saja menjadi sumber, kendala organisasi namun bisa juga menjadi sumber keuntungan organisasi. Kepemimpinan yang efektif bisa membantu organisasi untuk bias bertahan dalam situasi ketidakpastian di masa datang. Seorang pemimpin yang efektif harus tanggap terhadap perubahan, mampu menganalisis kekuatan dan kelemahan sumber daya manusianya sehingga mampu memaksimalkankinerja organisasi dan memecahkan masalah dengan tepat. Pemimpin yang efektif sanggup mempengaruhi para pengikutnya untuk mempunyai optimisme yang lebih besar, rasa percaya diri, serta komitmen kepada tujuan dan misi organisasi. Hal ini membawa konsekuensi bahwa setiap pemimpin berkewajiban untuk memberikan perhatian sungguh-sungguh dalam membina, menggerakkan dan mengarahkan seluruh potensi karyawan di lingkungannya agar dapat mewujudkan 
stabilitas organisasi dan peningkatan kinerja pegawai yang berorientasi pada tujuan organisasi.

Pada dasarnya karyawan yang puas terhadap pekerjaanya akan cenderung memiliki kinerja yang tinggi pula. Wexley dan Yuki $(2003 ; 129)$ menyatakan bahwa "kepuasan kerja dalah cara seorang pekerja merasakan pekerjaannya". Hubungan yang akrab dan saling tolong-menolong dengan teman kerja serta penyelia sangat penting dan memiliki hubungan kuat dengan kepuasan kerja dan tidak ada kaitannya dengan keadaan tempat kerja serta jenis pekerjaan. Hal ini menunjukkan bahwa kepemimpinan mempunyai hubungan yang positif terhadap kepuasan kerja para pegawai. Pemimpin yang dapat mendorong produktivitas kerja karyawan agar terus meningkat secara terus-menerus dengan cara memberikan kegiatan-kegiatan yang mepengaruhi bawahannya agar percaya bahwa hasil yang berharga bisa dicapai dengan usaha yang serius. Kepemimpinan yang berlaku secara universal menghasilkan tingkat produktivitas kerja dan kepuasan kerja bawahan yang tinggi.

Kinerja karyawan tidak lepas dari peran pemimpinnya. Peran pemimpin dalam memberikan kontribusi pada karyawan untuk pencapaian kinerja yang optimal dilakukan melalui lima cara, yaitu : (1) pemimpin mengklarifikasi apa yang diharapkan dari karyawannya, secara khusus tujuan dan sasaran dari kinerja mereka, (2) pemimpin menjelaskan bagaimana memenuhi harapan tersebut, (3) pemimpin mengemukakan kriteria dalam melakukan evaluasi dari kinerja secara efektif, (4) pemimpin memberikan umpan balik ketika karyawan telah mencapai sasaran, dan (5) pemimpin mengalokasikan imbalan berdasarkan hasil yang telah mereka capai.

Kinerja pegawai dapat dinilai dari apa yang dilakukan oleh seorang pegawai dalam kerjanya. Dengan kata lain, kinerja individu adalah bagaimana seorang pegawai melaksanakan pekerjaannya atau kerjanya. Kinerja pegawai yang meningkat akan turut meningkatkan prestasi organisasi tempat pegawai yang bersangkutan bekerja, sehingga tujuan organisasi yang telah ditentukan dapat dicapai. Untuk dapat mengevaluasi kinerja pegawai secara objektif dan akurat, maka perlu ada tolok ukur tingkat kinerja. Pengukuran tersebut berarti memberi kesempatan bagi pegawai untuk mengetahui tingkat kinerjanya.

Kinerja pegawai Kantor Urusan Agama Kabupaten Cilacap adalah perilaku penghulu dalam menetapkan sasaran kerja, pencapaian target sasaran kerja, cara kerja, dan sifat pribadi penghulu. Pegawai Kantor Urusan Agama Kabupaten Cilacap adalah seorang pegawai organisasi yang bergerak dalam bidang pelayanan umum baik untuk individu maupun kelompok. Keberhasilan Kantor Urusan Agama di Kabupaten Cilacap dalam menarik kepercayaan masyarakat tidak terlepas dari kinerja penghulunya.

Berdasarkan laporan pencapaian kinerja KUA dari Kemenag Kabupaten Cilacap diketahui bahwa kinerja KUA belum mencapai kinerja yang diharapkan yaitu: 
Tabel 1

Capaian Kinerja KUA Kabupaten Cilacap tahun 2017

\begin{tabular}{|l|c|c|}
\hline \multicolumn{1}{|c|}{ Indikator Kinerja } & Target & Realisasi \\
\hline $\begin{array}{l}\text { Mengadakan peningkatan sistem administrasi, dokumentasi dan } \\
\text { pelayanan publik }\end{array}$ & $100 \%$ & $89 \%$ \\
\hline $\begin{array}{l}\text { Meningkatkan kualitas SDM dan pelayanan publik dalam } \\
\text { pencatatan nikah dan rujuk }\end{array}$ & $100 \%$ & $90 \%$ \\
\hline $\begin{array}{l}\text { Meningkatkan pembinaan dan kualitas keluarga sakinah sehingga } \\
\text { terwujud kemandirian keluarga }\end{array}$ & $90 \%$ & $83,3 \%$ \\
\hline $\begin{array}{l}\text { Meningkatkan pembinaan sistem pengelolaan masjid, zakat, wakaf, } \\
\text { baitul maal dan visos yang profesional dan produktif untuk } \\
\text { meningkatkan kesejahteraan ummat }\end{array}$ & $90 \%$ & $79 \%$ \\
\hline $\begin{array}{l}\text { Mewujudkan pemahaman masyarakat dalam bidang pangan halal } \\
\text { dan kehidupan ummat beragama }\end{array}$ & $90 \%$ & $70 \%$ \\
\hline $\begin{array}{l}\text { Mewujudkan pelayanan haji yang memuaskan dan berkualitas } \\
\text { sehingga terwujud jama'ah haji yang mandiri }\end{array}$ & $90 \%$ & $80 \%$ \\
\hline
\end{tabular}

Sumber: Kemenag Cilacap, 2019

Berdasarkan tabel 1 terlihat bahwa pencapaian kinerja KUA di Kabupaten Cilacap belum memenuhi harapan. Kondisi tersebut dapat ditingkatkan dan perlu dilakukan evaluasi dan penelitian terhadap kualitas sumber daya manusia agar kebijakan yang diambil pada masa depan mampu meningkatkan kinerja pegawai dan meminimumkan faktor yang dapat menurunkan kinerja pegawai.

Berdasarkan hasil pengamatan sementara, realitas budaya organisasi, kepemimpinan, kepuasan kerja dan kinerja pegawai Kantor Urusan Agama Kabupaten Cilacap masih rendah, dengan fenomena sebagai berikut:

1. KUA Kabupaten Cilacap memiliki penghulu yang karakternya berbedabeda, sehingga akan menimbulkan perbedaan kemampuan para penghuludalam hal melaksanakan tugasnya. Tugas yang ada tidak dapat dikerjakan dengan efektif karena beberapa alasan, yaitu: terkendala masalah teknis dan masih kurangnya sarana penunjang dalam rangka penyelesaian pekerjaan;

2. Masih kurangnya tingkat pencapaian target/tujuan dalam penyelesaian

pekerjaan, sehingga prestasi kerja yang ada masih sedikit sulit dicapai;

3. Masih kurangnya tenaga yang mengerti pengeoperasian komputer secara maksimal;

4. Kepuasan kerja yang diraih masih kurang maksimal. Hal ini dikarenakan jumlah kompensasi atau gaji yang diterima masih dirasa kurang apabila dibandingkan dengan beban kerja yang harus dipertanggungjawabkan. Sebagian besar penghulu Kantor Urusan Agama di Kabupaten Cilacap saat ini memiliki beberapa kelemahan dan kekurangan yang menyebabkan kinerja penghulu kurang maksimal. Salah satu kelemahannya adalah minimnya perhatian terhadap kompensasi yang dirasa kurang mencukupi.

5. Masalah budaya organisasi yang baik belum tercapai yaitu: Integritas dari pegawai belum optimal, profesionalitas masih kurang, pegawai kurang inovatif dalam melaksanakan pekerjaan, tanggung jawab pegawai belum maskimal dan kurangnya keteladanan dari penghulu.

6. Masih adanya kecenderungan masyarakat yang berpikiran sempit 
dan sulit untuk diajak berpikir maju, sehingga perlu peningkatan penyuluhan kepada masyarakat secara intensif. Hal itu disebabkan karena heterogenitas pemahaman masyarakat terhadap ajaran agama dan secara mayoritas masyarakat Kabupaten Cilacap masih berada pada tingkat pendidikan SLTP ke bawah.

7. Rendahnya anggaran dana yang diberikan kepada KUA Kabupaten Cilacap dibanding beban tugasnya, sehingga ada beberapa kegiatan yang tidak mendapatkan pos anggaran dana yang berdampak kepada kepuasan kerja.

8. Rendahnya alat penunjang berupa sarana dan prasarana yang diberikan oleh pemerintah.

9. Kesempatan yang diberikan kepada pegawai KUA untuk mendapatkan pendidikan yang lebih tinggi masih kurang merata, seperti pendidikan pasca sarjana untuk menunjang tugas kepala KUA atau penghulu yang memangku jabatan struktural atau fungsional.

10. Belum adanya cetak biru program jangka pendek menengah dan panjang yang gradual, simultan dan tepat sasaran dari seluruh stake holder sehingga program-program yang dibuat bisa berdaya guna.

\section{KAJIAN PUSTAKA}

\section{Pengertian Budaya Organisasi}

Budaya organisasi sebagai unit sosial yang didirikan oleh manusia dalam jangka waktu yang relatif lama untuk mencapai tujuan dengan membentuk jiwa yang kuat agardapat menghadapi tugas-tugas yang diberikan dalam perusahaan. Selain itu budaya organisasi dapat mengajarkan tentang arti kebersamaan dalam mencapai tujuan dan tidak bersifat individualisme.

Menurut Davis (2004:29) budaya organisasi: "merupakan pola keyakinan dan nilai-nilai organisasi yang dipahami, dijiwai dan dipraktekkan oleh organisasi sehingga pola tersebut memberikan arti tersendiri dan menjadi dasar aturan berperilaku dalam organisasi sehingga mempunyai volume dan beban kerja yang harus diwujudkan guna mencapai tujuan organisasi”. Hal yang sama juga diungkapkan oleh Mangkunegara (2005: 113) yang menyatakan bahwa:" budaya organisasi adalah seperangkat asumsi atau sistem keyakinan, nilai-nilai, dan norma yang dikembangkan dalam organisasi yang dijadikan pedoman tingkah laku bagi anggota-anggotanya untuk mengatasi masalah adaptasi eksternal dan internal".

Dengan demikian dapat disimpulkan bahwa budaya organisasi merupakan pola keyakinan dan nilai-nilai organisasi yang diyakini dan dijiwai oleh seluruh anggotanya dalam melakukan pekerjaan sebagai cara yang tepat untuk memahami, memikirkan, dan merasakan terhadap masalah-masalah.

\section{Kepemimpinan}

Kepemimpinan atau leadership berarti being a leader power of leading, atau the qualities of leader. Secara makna kata, kepemimpinan itu adalah kemampuan dan kesiapan yang dimiliki oleh sesorang untuk dapat mempengaruhi, mendorong, mengajak, menuntun, menggerakan, mengarahkan, dan kalau perlu memaksa orang atau kelompok agar menerima pengaruh tersebut dan selanjutnya berbuat sesuatu yang dapat membantu tercapainya suatu tujuan tertentu yang telah ditetapkan. (Tim Dosen AP UPI Bandung, 2009: 125)". Sedangkan Danim (2010: 8-9) mengemukakan bahwa terdapat banyak teori kepemimpinan. Dari sekian banyak teori tentang kepemimpinan itu dikemukakan tujuh jenis teori kepemimpinan, yaitu: "a. Teori genetis. b. Teori sifat. c. Teori kontigensi. d. Teori situasional. e. Teori perilaku. f. Teori partisipatif. g. Teori transformasional. Danim (2010: 9-10) mengemukakan bahwa dalam teori Kurt Lewin terdapat tiga 
gaya kepemimpinan utama yang sangat berpengaruh bagi pengembangan teori kepemimpinan. Ketiga gaya tersebut adalah: 1) Gaya kepemimpinan otoriter. 2) Gaya kepemimpinan partisipatif. 3) Gaya kepemimpinan delegatif."

\section{Pengertian Kepuasan}

Menurut Mathis terjemahan Prawira (2001: 98), "kepuasan kerja adalah keadaan emosi yang positif dari mengevaluasi pengalaman kerja seseorang”. Kepuasan kerja mencerminkan perasaan seseorang baik yang tidak menyenangakan terhadap pekerjaannya. Perasaan senang karyawan akan nampak pada sikap positifnya terhadap pekerjaan dan segala sesuatu yang dihadapi dilingkungan kerjanya. Seperti yang dinyatakan oleh Locke (Luthan. 2005: 126) bahwa: "Kepuasan kerja adalah suatu keadaan emosi yang menyenangkan atau positif sebagai akibat dari pengalaman atau penilaian kerja seseorang. Lebih lanjut dikatakan bahwa kepuasan kerja dari persepsi tentang bagaimana baiknya pekerjaan memberikan sesuatu yang berarti".

\section{Pengertian Kinerja}

Sedarmayanti (2007:259), Kinerja terjemahan dari "performance" yang berarti:

a. Perbuatan, pelaksanaan pekerjaan, prestasi kerja, pelaksanaan pekerjaan yang berdaya guna b. Pencapaian/prestasi berkenan dengan tughas yang diberikan kepadanya.

c. Hasil kerja seorang pekerja, sebuah proses manajemen atau suatu organisasi secara keseluruhan, dimana hasil kerja tersebut harus dapat ditunjukkan buktinya secara konkrit dan dapat diukur (dibandingkan dengan standar yang telah ditentukan)

d. Hasil kerja yang dapat dicapai seseorang atau sekelompok orang dalam suatu organisasi sesuai dengan wewenang dan tanggung jawab masing-masing, dalam rangka upaya mencapai tujuan organisasi bersangkutan secara legal, tidak melanggar hukum dan sesuai dengan moral maupun etika.

Mathis dan Jackson (2006:78) menyatakan bahwa :" kinerja pada dasarnya adalah apa yang dilakukan atau tidak dilakukan karyawan.

\section{Metode Penelitian}

Penelitian ini dilaksanakan dengan menggunakan metode deskriptif analisis dengan teknik survey dengan analisis jalur. Pada penelitian ini peneliti menganalisis Pengaruh Budaya Organisasi dan Kepemimpinan terhadap Kepuasan Kerja dan Dampaknya terhadap Kinerja Pegawai Kantor, dengan model sebagai berikut:

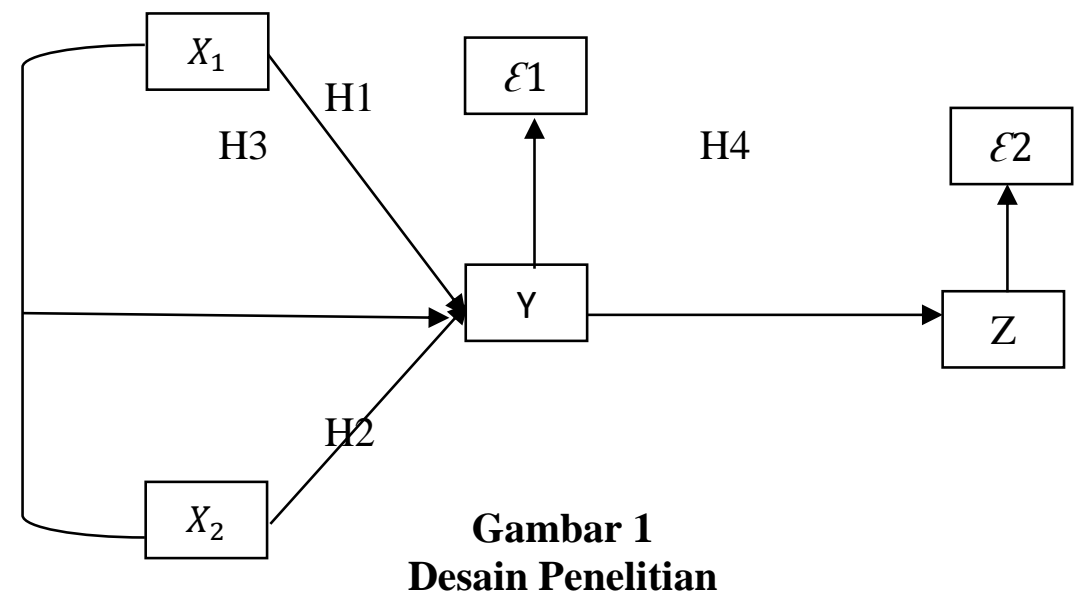


Keterangan :

$\mathrm{X}_{1}$ : Budaya Organisasi

$\mathrm{X}_{2}$ : Kepemimpinan

$\mathrm{Y}$ : Kepuasan

$\mathrm{Z}$ : Kinerja

$\varepsilon 1$ : Epsilon 1

$\varepsilon 2$ : Epsilon 2

Sebelum alat ukur (kuesioner) digunakan, terlebih dahulu dilakukan uji validitas dan uji reliabilitas. Uji validitas dimaksudkan untuk mengetahui apakah instrumen yang digunakan tepat atau sudah mengukur apa yang seharusnya diukur. Oleh karena itu, uji validitas dilakukan pada setiap item dalam kuesioner. Kriteria pengujian validitas, yaitu jika rxy >0,30, maka item dari instrumen tersebut dikataka valid. Demikian pula berlaku sebaliknya, jika rxy <0,30, maka item dari instrumen tersebut dikatakan tidak valid. Sementara untuk uji reliabilitas, yakni untuk mengetahui keandalan instrumen digunakan metoda belah dua (split half method). Metoda belah dua dilakukan dengan cara membagi instrumen menjadi dua belahan, bisa ganjil-genap dan bisa pula belahan pertama dan kedua, untuk kemudian kedua belahan tersebut dikorelasikan dengan menggunakan rumus yang sama di atas. Kriteria pengujian reliabilitas, yaitu jika rxy >0,70, maka instrumen dari variabel penelitian tersebut

dikatakan reliabel. Demikian juga sebaliknya, jika rxy $<0,70$, maka instrumen dari variabel penelitian tersebut dikatakan tidak reliabel. Hasil uji validitas terhadap variabel penelitian, diketahui bahwa seluruh item dari tiap variabel dinyatakan valid dan reliabel, sehingga tidak perlu ada item yang dibuang.

\section{HASIL PENELITIAN DAN \\ PEMBAHASAN}

Untuk mengetahui seberapa besar pengaruh budaya organisasi dan kepemimpinan terhadap kinerja melalui kepuasan penghulu Kantor Urusan Agama di Kabupaten Cilacap, maka diperlukan data yang diperoleh dari frekuensi jawaban pegawai. Uji statistik dilakukan dengan uji statistik parametrik yang mensyaratkan jenis jenis data (skala pengukuran data) minimal berjenis interval, maka data berskala ordinal ditransformasikan ke dalam bentuk skala interval dengan menggunakan successive interval method dengan hasil sebagai berikut:

Coefficients $^{\text {a }}$

\begin{tabular}{|rl|r|r|r|r|r|}
\hline \multirow{2}{*}{ Model } & \multicolumn{2}{|c|}{$\begin{array}{c}\text { Unstandardized } \\
\text { Coefficients }\end{array}$} & $\begin{array}{c}\text { Standardized } \\
\text { Coefficients }\end{array}$ & \multirow{2}{*}{ Sig. } & \\
\cline { 2 - 5 } & \multicolumn{1}{|c|}{$\mathrm{B}$} & \multicolumn{1}{c|}{ Std. Error } & \multicolumn{1}{c|}{ Beta } & & \\
\hline \multirow{2}{*}{1} & (Constant) & 4.740 & 2.263 & & 2.095 & .041 \\
& Budaya Organisasi & .307 & .148 & .319 & 2.079 & .042 \\
& Kepemimpinan & .311 & .151 & .316 & 2.058 & .044 \\
\hline
\end{tabular}

a. Dependent Variable: Kinerja

Berdasarkan data pada Tabel di atas dapat digambarkan pengaruh budaya organisasi (X1) dan Kepemimpinan (X2) terhadap Kinerja (Z) melalui kepuasan pegawai (Y) sebagai berikut : 


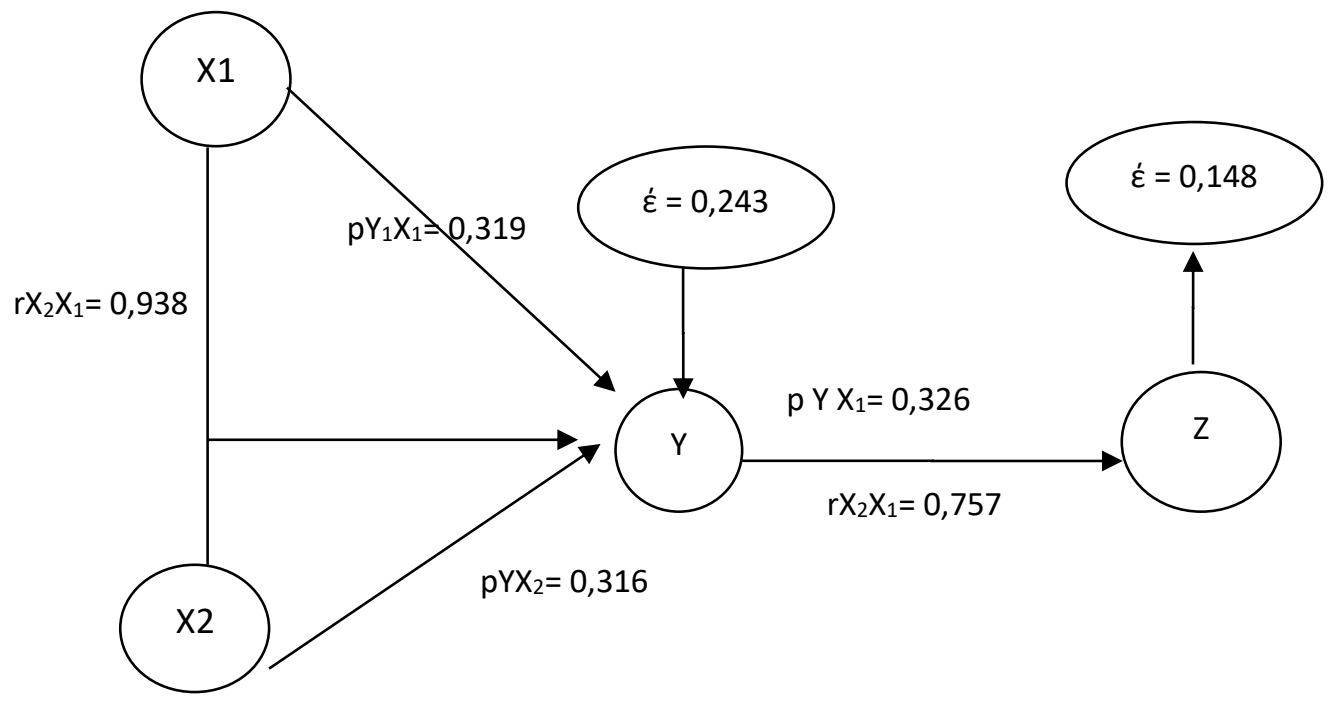

Hasil penelitian menunjukkan terdapat pengaruh signifikan budaya organisasi dan kepemimpinan terhadap kinerja melalui kepuasan pegawai pada Kantor Urusan Agama Kabupaten Cilacap. Adanya keterkaitan hubungan antara budaya organisasi dengan kinerja yang dapat dijelaskan dalam model diagnosis budaya organisasi berpengaruh pada kinerja, bahwa semakin baik kualitas faktor-faktor yang terdapat dalam budaya organisasi makin baik kinerja organisasi tersebut (Moelyono, 2003 : 42). Seperti yang dikatakan oleh Rogga (2001:17) yang menyatakan bahwa budaya organisasi dapat meningkatkan kepuasan kerja karyawan. Sesungguhnya antar budaya perusahaan dengan kepuasan karyawan terhadap hubungan, dimana budaya (culture) dikatakan memberi pedoman seorang karyawan bagaimana dia mempersepsikan karakteristik budaya suatu organisasi, nilai yang dibutuhkan karyawan dalam bekerja, berinteraksi dengan kelompoknya, dengan sistem dan administrasi, serta berinteraksi dengan atasan. Kepuasan kerja mencerminkan perasaan seseorang terhadap pekerjaannya. Ini nampak dalam sikap positif karyawan terhadap pekerjaan dan segala sesuatu yang dihadapi di lingkungan kerjanya (Faizal et al., 2019). Pada dasarnya makin positif sikap kerja makin besar pula kepuasan kerja, untuk itu berbagai indikator dari kepuasan kerja perlu memperoleh perhatian khusus agar pekerja dapat meningkatkan kinerjanya. Pada umumnya seseorang merasa puas dengan pekerjaanya karena berhasil dan memperoleh penilaian yang adil dari pimpinannya.

Secara konsep kepuasan kerja memiliki hubungan dengan tingkat kinerja pekerja. Menurut konsep Value Theory, kepuasan kerja terjadi pada tingkatan di mana hasil pekerjaan diterima individu seperti yang diharapkan. Semakin banyak orang menerima hasil, akan semakin puas. Dengan terciptanya kepuasan kerja yang merupakan sikap positif yang dilakukan individual terhadap pekerjaan mereka, maka akan tercapainya kinerja individual tersebut (Wibowo, 2007:27). Selain itu dengan adanya kepuasan kerja dapat mengurangi turnover, dan mendorong individu Teori lain yang memperkuat hubungan kepuasan kerja dengan kinerja adalah teori dua faktor atau teori motivasi higiene, yang dikemukakan oleh seorang psikolog bernama Herzberg (1923-2000). Menurut teori ini, faktor motivasi (intrinsic factor) adalah: pekerjaan itu sendiri (the work it self), prestasi yang diraih (achievement), peluang untuk maju (advancement), pengakuan orang lain (ricognition), tanggung jawab (responsible). Faktor motivasi (intrinsic 
factor) merupakan faktor yang mendorong semangat guna menyenangi pekerjaan yang memungkinnya menggunakan kreativitas dan inovasinya (Robbins, dan Judge, 2007:174).

Selain itu hubungan positif antara kepuasan kerja dengan kinerja diperkuat oleh pendapat yang dikemukakan oleh Robbins dan Judge (2007:174), yang menyatakan bahwa organisasi yang mempunyai karyawan yang lebih puas cenderung lebih efektif bila dibandingkan organisasi yang mempunyai karyawan yang kurang puas.

Hasil penelitian yang dilakukan Ostroff (1992), menunjukkan hubungan positif antara kepuasan kerja dengan kinerja karyawan. Selanjutnya diungkapkan lebih khusus, organisasi dengan karyawan yang lebih puas, berkomitmen, sesuai dan tidak stress tinggi akan memiliki tingkat kinerja yang lebih tinggi daripada karyawan yang kurang puas, kurang berkomitmen, kurang mampu menyesuaikan dan lebih banyak mengalami stress.

\section{SIMPULAN DAN SARAN}

Berdasarkan hasil analisis data dengan menggunakan path analysis dan pembahasan hasil penelitian yang telah dikemukakan sebelumnya, dapat disimpulkan bahwa budaya organisasi berpengaruh positif terhadap kepuasan penghulu sebesar $73,4 \%$. Kepemimpinan berpengaruh positif terhadap kepuasan pegawai sebesar $73,4 \%$. Budaya organisasi dan kepemimpinan berpengaruh positif terhadap kepuasan penghulu sebesar 75,7\%. Budaya organisasi dan kepemimpinan melalui berpengaruh positif terhadap kinerja penghulu melalui kepuasan pegawai sebesar 85,2\%. Berdasarkan dari hasil analisis dan pembahasan maka dapat disarankan sebagai berikut: Kepala KUA di Kabupaten Cilacap diharapkan dapat menciptakan budaya organisasi yang baik dengan cara selalu memberikan pengarahan tentang pekerjaan, membina hubungan kerja yang baik antara pegawai sehingga tercipta suasana dan lingkungan kerja yang kondusif dengan mengacu kepada standar pelayanan minimal. Kepala Kantor Urusan Agama Kabupaten Cilacap sebaiknya lebih diperbaiki agar diikuti oleh seluruh bawahannya dengan menerapkan gaya kepemimpinan kontingensi sehingga dapat diterima oleh semua pegawai. Pola evaluasi dan pengawasan pimpinan terhadap kinerja bawah sebaiknya dievaluasi terutama dalam pemberian reward untuk menciptakan kepuasan kerja penghulu.

\section{DAFTAR PUSTAKA}

Dessler, Gary. 2011. Manajemen Sumber Daya Manusia. Saduran Paramita Rahayu. Edisi kesepuluh. Indeks. Jakarta

Faizal, R., Sulaeman, M., \& Yulizar, I. (2019). Pengaruh Budaya, Motivasi

Kerja Dan Kompetensi Terhadap Kinerja Karyawan. EBA Journal: Journal Economics, Bussines and Accounting, 5(1), 11-21. https://doi.org/10.32492/eba.v5i1.706

George R. Terry ,2008. Prinsip-Prinsip Manajemen. (edisi bahasa Indonesia). PT. Bumi Aksara: Bandun

Gibson, Ivansevich, and Donelly, 2003, Organisasi: Perilaku, Struktur, Proses, Jilid 2, Binarupa Aksara, Jakarta.

Hasibuan, Malayu SP.2006. Manajemen Sumber Daya Manusia. Edisi Kesebelas. PT Bumi Aksara. Jakarta Mangkunegara, Anwar Prabu. (2013). Manajemen Sumber Daya Manusia Perusahaan. Bandung : PT. Remaja Rosda Karya.

Mathis, Robert L. dan Jackson, John H. 2006. Manajemen Sumber Daya 
Manusia. Saduran. Edisisepuluh. Salemba Empat. Jakarta

Mondy, R Wayne. 2008. Manajemen Sumber Daya Manusia. Saduran Bayu Airlangga. Edisi kesepuluh. Erlangga. Jakarta

Nawawi, Hadari. 2010. Manajemen Sumber Daya Manusia Untuk Bisnis Yang Kompetitif. Gadjah Mada University Press. Yogyakarta

Noe, Raymond A. Hollenbeck, John R. Gerhart, Barry. Wright, Patrick M. 2011. Manajemen Sumber Daya Manusia: Mencapai Keunggulan Bersaing. Saduran David Wijaya. Edisi 6.Salemba Empat. Jakarta

Robbin, Stephen P, (2000), Perilaku Organisasi Konsep, Kontroversi, Aplikasi, Prenhalindo, Jakarta

Samsudin, Sadili. 2009. Manajemen Sumber Daya Manusia. Cetakan Kedua. CV Pustaka Setia. Bandung

Sedarmayanti. 2008. Manajemen Sumber Daya Manusia, Reformasi Birokrasi Dan Manajemen Pegawai Negeri Sipil. PT Refika Aditama. Bandung

Wibowo, (2013), Perilaku Dalam Organisasi, Cetakan Pertama, PT. Rajagrafindo Persada, Jakarta. 